\title{
RELATIONSHIP BETWEEN CHILDREN'S RHYTHMICITY AND
}

\section{MOTHER'S TEMPERAMENT}

\section{REETU DEVI ${ }^{1}$, SHANTI BALDA ${ }^{2} \&$ PINKI RANI ${ }^{3}$}

${ }^{1}$ Research Scholar, Department of Human Development and Family Studies, COHS, CCS HAU Hisar, Haryana, India

${ }^{2}$ Professor, Department of Human Development and Family Studies, COHS, CCS HAU Hisar, Haryana, India

${ }^{3}$ Assistant Professor, Department of Home Science, FGM Government College, Adampur, Haryana, India

\begin{abstract}
Temperament refers to our inborn personality traits, which are genetic in nature. The different ways infants interact with and react to their environment and experiences are reflective of their temperament, or behavioral style. The present study was conducted in Hisar district of Haryana state. From Hisar district village Dobhi was selected purposively. 50 boys and 50 girls in the age group of 6 to 8 years and their mothers were selected randomly from village Dobhi. Hence, the total sample for the study was 200 (50 boys and 50 girls and 100 mothers). There were two types of variables in the study, i.e. independent and dependent variable. A dependent variable is a variable presumed to be affected by one or more independent variables. Mother-child Interaction was taken as the dependent variable. Inventory was prepared and used. Result revealed that children's rhythmicity was significantly correlated with sociability (0.19*), vigorous $(0.18 *)$ and persistence $(0.19 *)$ dimensions of mother's temperaments. A positive trend was observed between children's rhythmicity and impulsivity, accepting, responsible and tough-minded dimensions of maternal temperament.
\end{abstract} KEYWORDS: Temperament, Emotions, Sociability, Warmth, Tolerance \& Mother's Temperament

Received: Apr 06, 2018; Accepted: Apr 27, 2018; Published: May 03, 2018; Paper Id.: IJESRJUN20186

\section{INTRODUCTION}

Temperament refers to our inborn personality traits, which are genetic in nature. The different ways infants interact with and react to their environment and experiences are reflective of their temperament, or behavioral style. All children have a temperament that will influence their emotions and how they adapt to change in their environments (Steinberg, 2014). Temperamental stability is influenced by both biological and environmental factors, as well as cultural factors in some cases.

Children are born with their natural style of interacting with or reacting to people, places, and things. This natural behavior style in everyday situations is known as temperament. The child with an easy temperament is always cheerful, easily accepts new foods, and makes little fuss about ordinary frustration and smiles at everyone. The child with a difficult temperament does not establish regular eating and sleeping patterns, requires a long time to new routines, is happy and unfriendly, is likely to throw tantrums at the slightest frustration. The child with slow-to-warm temperament does not take to most new offerings the first time but given time, the child will become interested in and even enjoy, these additions to his or her life. These children are mild in their reaction and they are somewhat irregular in habits. 
Temperament is a recent and rapidly growing area in psychology as the role of temperament in influencing developmental pathways and outcomes has now been recognized. Extreme difficult temperament is often viewed as a risk factor for later behavior problems (Hill, 2012). Temperament defined as person emotional and behavioral modes of response to environmental events (Shaffer and Kipp, 2007).

Parents often do not become believers in temperament until after the birth of their second child. Before this time, their child's behavior may be seen as the simple and direct outcome of their upbringing. With the second child, management strategies that worked well with the first child may not be effective. Problems experienced with the first child (in feeding, sleeping, coping with strangers) may not exist with the second, but new problems may arise. Such experiences suggest strongly that "nature" as well as "nurture" influences child development, that children differ from each other from very early in life, and that these differences have important implications for parent-child interaction (Sanson and Rothbart2002)

Carolyn and Sheila (2009) examined child temperament and its relationship with child behavior problems and quality of mother-child interactions. Children who were perceived by their mothers as more active with a low attention span, tended to have more behavior problems and to be more non-accepting or noncompliant in their interactions with their mothers. Mothers of active children, in turn, were described as more negative and non-accepting in their responses to their children. Hence, mother-child interaction is influenced by the temperament of children and vice-versa.

\section{OBJECTIVE}

- To study the correlations between children's rhythmicity and mother's temperament.

\section{METHODOLOGY}

Hisar district of Haryana state was selected for the present study. From Hisar district village Dobhi was selected purposively. 50 boys and 50 girls in the age group of 6 to 8 years were selected randomly from village Dobhi. The mothers of these children also participated in the study. Hence, the total sample for the study was 200 (50 boys and 50 girls and 100 mothers). There were two types of variables in the study, i.e. independent and dependent variable. A dependentvariable is a variable presumed to be affected by one or more independent variables. Mother-child Interaction was taken as the dependent variable. Inventory was prepared and used.

\section{RESULTS AND DISCUSSIONS}

\section{Correlations between Children's Rhythmicity and Mother's Temperament}

Correlations were computed to examine the relationship between child's temperament and mother's temperament. A few mild correlations were obtained between the child's and mother's temperament.

As shown in Table 1 children's rhythmicity was significantly correlated with sociability $\left(0.19^{*}\right)$, vigorous $\left(0.18^{*}\right)$ and persistence $(0.19 *)$ dimensions of mother's temperaments. A positive trend was observed between children's rhythmicity and impulsivity, accepting, responsible and tough-minded dimensions of maternal temperament. 
Table 1: Correlations between Children's Rhythmicity and Mother's Temperament

\begin{tabular}{|l|c|}
\hline \multirow{2}{*}{$\begin{array}{c}\text { Mother's Temperamental } \\
\text { Dimensions }\end{array}$} & Child's Temperament \\
\cline { 2 - 2 } & Rhythmicity \\
\hline Sociability & $0.19^{*}$ \\
\hline Ascendant & 0.09 \\
\hline Secretiveness & 0.06 \\
\hline Reflective & 0.01 \\
\hline Impulsivity & 0.16 \\
\hline Placid & 0.08 \\
\hline Accepting & 0.15 \\
\hline Responsible & 0.13 \\
\hline Vigorous & $0.18^{*}$ \\
\hline Cooperative & 0.07 \\
\hline Persistence & $0.19^{*}$ \\
\hline Warmth & 0.04 \\
\hline Aggressiveness & 0.04 \\
\hline Tolerance & 0.05 \\
\hline Tough -minded & 0.10 \\
\hline *Significant at 5\% level & \\
\hline
\end{tabular}

\section{CONCLUSIONS}

Children who were high on rhythmicity dimensions of temperament had mothers who were high on ascendant, reflective, sociability, impulsivity, placid, accepting, vigorous, persistence and aggressiveness dimensions of temperament. Reflective, sociability, placid, accepting and persistence are indicators of easy temperament, while high on the ascendant, impulsivity, vigorous and aggressiveness dimensions are indicators of difficult temperament. It can be interpreted that mothers intentionally controlled their temperament to fit with their distractible children.

It is, therefore, important that parents get a clear picture of their own temperament traits. Conflicts between parents and their children may arise due to temperament clashing. When there is temperament friction between parent and child, it is more reasonable to expect that the parent should make the first move to adapt. When a parent or caregiver understands the child's temperament, he or she can organize the environment so that "goodness of fit" happens (Kathy, 2002). Caregivers and families can also use their understanding of temperament to avoid blaming themselves or a child for reactions that are normal for that particular child (Allard and Hunter, 2014).

\section{REFERENCES}

1. Allard, L. T. and Hunter, A. 2014. Developing a strong, beneficial relationship with your child. Retrieved from <http://csefel.vanderbilt.edu/resource/parenting-difficult-child.

2. Anonymous.2011. Temperament and Parenting - Temperament.com. Retrieved from https://www.b-di.com/temperament. comfaqs.html

3. Costa, P. T. and McCare, R. R. 2000. Nature over nurture : Temperament, personality and life span development. Journal of Personality and Social Psychology, 78 (1) : 173-186.

4. Griggs, M. S., Gagnon, S. G., Huelsman, T. J., Kidder-Ashley, P. and Ballard, M. 2009. Student-teacher relationships matter: Moderation influences between temperament and preschool social competence. Psychology in the Schools.46 : 553-566.

5. Kashyap, I. 2013. Temperament and development domains, Unpublished Masters Thesis, HDFS, CCSHAU, Hisar. 
6. Kathy, K. O.2002. Understanding Your Child's Temperament. Family Life Month Packet.5 : 1-2.

7. Kohnstamm, G. 1989. Temperament in Childhood: cross-cultural and sex differences. In G. A. Kohnstamm, J. E. Bates and M. K. Rothbart (Eds), Temperament in Childhood (pp.483-508). New York: Wiley.

8. Kumari, V. 2011. Temperament, interpersonal competence and socio-metric status of 6 to 8 years old children. Ph. D. Dissertation. Department of Human Development and Family Studies, I. C. College of Home Science, CCS Haryana Agricultural University, Hisar.

9. Malhotra, S. and Malhotra, A. 1988. Malhotra's Temperament Schedule. National Psychogical Corporation. Agra.

10. Prior, M., Smart, D., Sanson, A. V. and Oberklaid, F. 1993. Sex differences in psychological adjustment from infancy to 8 years. Journal of the American Academy of Child and Adolescence Psychiatry, 32 : 291-304.

11. Rothbart, M. K. and Bates, J. 2006. Temperament. In W. Damon (Series Ed), \& N. Eisenberg (Vol. Ed), Handbook of child psychology: Social emotional and personality development (Vol. 3, 6th ed., pp. 99-166). New York: Wiley.

12. Sanson, A. and Rothbart, M. K. 2002. Child temperament and parenting. In M. Bornstein (Ed.), Applied and practical parenting (Vol. 4, pp. 299-321). Mahwah, NJ: Lawrence Erlbaum.

13. Allawi, Ali Abdulmajid Dyab, Jawad Ibrahim Rasheed, and Mohammed Younus Naji Al Atbee. "Relationship of Fetuin-A and Coronary artery calcification in hemodialysis patients." Age 55.6: 10.

14. Steinberg, L. 2004. The 10 basic principles of good parenting. New York, NY: Simon \& Schuster Paperbacks.

15. Thomas, A. and Chess, S. 1989. Temperament and personality. In: GA Kohnstamm, JE Bates and MK Rothbart (Eds.): Temperament in Childhood. New York: John Wiley and Sons, pp. 249-261.

16. Walker, S., Berthelsen, D. and Irving, K. 2001. Temperament and peer acceptance in early childhood: Sex and social status differences. Child Study Journal, 31 : 177-192.

17. Vig., D. and Jaswal, J. S. 2008. Impact of Parental Stress on Their Relationship with Teenage Children. Home Comm. Sci. 2(1): 51-57. 